\title{
Technical, Economic, Social and Regulatory Feasibility Evaluation of Dynamic Distribution Tariff Designs
}

\author{
Kristoffer Christensen ${ }^{1, *(\mathbb{D})}$, Zheng $\mathrm{Ma}^{2} \mathbb{D}$ and Bo Nørregaard Jørgensen ${ }^{1}(\mathbb{D}$ \\ 1 Center for Energy Informatics, University of Southern Denmark, Campusvej 55, 5230 Odense, Denmark; \\ bnj@mmmi.sdu.dk \\ 2 Center for Health Informatics and Technology, University of Southern Denmark, Campusvej 55, 5230 Odense, \\ Denmark; zma@mmmi.sdu.dk \\ * Correspondence: kric@mmmi.sdu.dk
}

Citation: Christensen, K.; Ma, Z; Jørgensen, B.N. Technical, Economic, Social and Regulatory Feasibility Evaluation of Dynamic Distribution Tariff Designs. Energies 2021, 14, 2860 https://doi.org/10.3390/en14102860

Academic Editor: Junemo Koo

Received: 12 April 2021

Accepted: 11 May 2021

Published: 15 May 2021

Publisher's Note: MDPI stays neutral with regard to jurisdictional claims in published maps and institutional affiliations.

Copyright: (c) 2021 by the authors. Licensee MDPI, Basel, Switzerland. This article is an open access article distributed under the terms and conditions of the Creative Commons Attribution (CC BY) license (https:// creativecommons.org/licenses/by/ $4.0 /)$.

\begin{abstract}
The increasing number of distributed energy resources in the distribution grids creates the risk of grid congestion and the high cost of grid expansion. The implementation of the dynamic distribution grid tariffs can potentially avoid grid congestion. Meanwhile, the design and implementation of any distribution tariff need to consider and match the regional/national requirements. However, there is no sufficient evaluation method available to review and evaluate the feasibility of the dynamic distribution tariffs. Therefore, this paper introduces a feasibility evaluation method with four dimensions of technical, economic, social, and regulatory to review dynamic distribution tariffs. The literature on dynamic distribution tariffs is collected, and 29 dynamic distribution tariffs are selected and further categorized into five attributes of rationale, cost drivers, dynamics, events, and active demand. The evaluation results show that the time-of-use tariff is the most feasible dynamic distribution tariff, and the review of a proposed future distribution tariff model in Denmark verifies the evaluation method and results. The developed feasibility evaluation method for dynamic distribution tariffs can ensure the design and implementation of a dynamic distribution tariff to be feasible and applicable in a region.
\end{abstract}

Keywords: scoping review; dynamic distribution tariff; feasibility evaluation; technology readiness; participation cost; user convenience level; regulatory readiness

\section{Introduction}

Due to the increasing number of Distributed Energy Resources (DERs) in the distribution grids, e.g., Electric Vehicles (EVs), batteries, heat pumps, PhotoVoltaic (PV), and the introduction of other smart technologies, the patterns of energy demand have been changing in the distribution network, both in Europe and worldwide [1]. From the demand side, these changes provide opportunities and benefits, such as using electricity when the price is low or financial gains by producing electricity [2]. However, from the distribution grid perspective, these changes create the risks of grid congestion and the high cost of grid expansion [3]. The DSO has to develop new tools for monitoring and controlling a more active distribution network with the use of sensors, such as smart meters. The tools should be based on real-time algorithms, online optimization solutions, forecasting systems, etc. [3]. One potential solution to avoid grid congestion is to implement dynamic distribution grid tariffs.

Dynamic Distribution Tariffs (DDTs) aim to motivate consumers to reduce or shift their flexible energy consumption and create incentives for consumers to participate in Demand Response (DR) programs [4]. Energy flexibility on the demand side refers to the possibility of increasing or reducing the energy consumption of a demanding process $[5,6]$. DR is defined by the European Commission as the intentional modification of normal consumption patterns by end-users in response to incentives from grid operators [7]. DR programs are expected to reduce the use of peak load generation and electricity cost, and 
improve system reliability [8]. DR programs aim to incentivize changes in the electricity consumption patterns in response to the varying electricity prices [9].

However, the design and implementation of DDTs have to comply with the national/regional regulations. Distribution grid tariffs are the main revenue stream for Distribution System Operator (DSOs) and are determined by a revenue frame regulation. The revenue via the DSO tariff is regulated to make sure reasonable tariffs to consumers. For instance, in Denmark, according to $\$ 73$ in the Danish law of electricity supply [10], the determination of the electricity suppliers' service prices should be equitable, objective, and non-discriminative. According to $\$ 69$ in the Danish law of electricity supply [10], the revenue from grid services for grid companies is determined by the supply authority once a year. Price differentiation for more efficient utilization of the electricity grid and security of supply is allowed. However, price differentiation based on geographical delimitation is only allowed in specific cases.

Although several DDTs, e.g., Real-Time Pricing (RTP), Time-of-Use (ToU), Critical Peak Pricing (CPP), etc., have been introduced and discussed in the literature, there is no systemic review of different DDTs. Meanwhile, the implementation potentials of any DDT need to consider and match the regional/national requirements. The regional/national requirements not only include the technological aspect, but also economic, and regulatory aspects [11-13]. However, such feasibility evaluation for DDTs is missing in the literature.

To fill this gap, this paper develops a feasibility evaluation method to evaluate DDT designs. The feasibility evaluation method includes four aspects: technical, economic, social, and regulatory feasibility. To introduce and demonstrate the developed feasibility evaluation method, this paper conducting a scoping review in the IEEE Xplore database. A total of 29 references were selected and further categorized into five attributes of rationale, cost drivers, dynamics, events, and active demand.

This paper firstly introduces the scoping review approach and the feasibility evaluation method in the Methodology section. Afterward, the DDTs found in the literature are analyzed and categorized into 16 combined attributes, and introduced in the Section of Analysis and evaluation of dynamic distribution tariffs. Furthermore, the evaluation results with the technical, economic, and regulatory aspects are also presented in the same section. In the Discussion section, a DDT potentially implemented in Denmark is discussed that demonstrates that the feasibility evaluation can ensure the selected DDTs to be potentially implemented in the region.

\section{Methodology}

\subsection{Literature Search}

To investigate various types of DDTs in the literature, this paper conducts a scoping review search. Compared to other review methods, such as narrative or traditional literature reviews that usually focus on a specific type of dynamic tariffs or specific purposes, the scoping review approach investigates all available literature under a designed scope with thorough literature analysis. Therefore, the scoping review approach not only can provide an overview of the related literature but also comprehensive search results and analysis of available dynamic tariffs in the literature.

Several databases, e.g., ACM digital library, IEEE Xplore, Web of Science, ScienceDirect have been considered, and the literature search is only conducted in the IEEE Xplore database because the publication in this database is more multi-disciplinary oriented, and the main purpose of the paper is to introduce the feasibility evaluation method and evaluate DDTs with five aspects.

The following search string is designed and initially searched in the IEEE Xplore database: (Dynamic OR Variable OR (Day-ahead OR Day ahead) OR Changing) AND (Tariff OR Pricing OR Cost).

The search string above resulted in many but not relevant results. Therefore, the search string is modified to be "((("Document Title":Dynamic) OR ("Document Title":Variable)) AND ((“Document Title":Tariff)))", and this results in 50 articles. After the duplication 
check and relevance check, 29 relevant articles with full text are selected for further categorization analysis (shown in Table 1).

Table 1. Literature on dynamic distribution tariffs.

\begin{tabular}{c}
\hline Title \\
\hline \\
Electric Vehicle (EV) Charging Management
\end{tabular}

with Dynamic Distribution System Tariff

Reference DDT Type

[14] RTP

The Impact of Dynamic Electricity Tariff on

Long-Run Incremental Cost

Dynamic Tariff Method for Congestion

Management in Distribution Networks

[16] RTP

Grid Expansion Costs Considering Different

Price Control Strategies of Power-to-X Options

Based on Dynamic Tariffs at the Low-Voltage

Level

Dynamic Tariff-Subsidy Method for PV and V2G

Congestion Management in Distribution

Networks

Optimal Reconfiguration-Based Dynamic Tariff

for Congestion Management and Line Loss

Reduction in Distribution Networks

pumps.

Proposes a smart charging algorithm with the dual objectives of minimizing charging costs and preventing grid congestion. EVs are charged according to individual user requirements while respecting the constraints of the local distribution grid. A day-ahead DDT scheme is proposed to avoid congestion on the local distribution system from the day-ahead planning perspective.

Investigates the effect of DDT and flexible demand on Long run incremental cost and network investment decisions are deeply analyzed and discussed.

This paper puts forward a congestion management way for distribution networks considering electric vehicles and heat pumps.

This paper examines grid extensions caused by different control strategies of Power-to- $X$ options. The focus is on a price-controlled control strategy that dynamizes fees and levies to improve the integration of high PV feed-in.

This paper proposes a dynamic tariff-subsidy method for

[18] RTP $\begin{aligned} & \text { congestion management in distribution networks with high } \\ & \text { penetration of PV, heat pumps, and EVs with vehicle-to-grid }\end{aligned}$

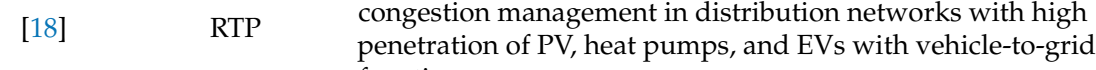
function. This paper presents an optimal reconfiguration-based DDT [19] RTP method for congestion management and line loss reduction in distribution networks with high penetration of electric vehicles.

This paper demonstrates the efficacy of the uncertainty management of the dynamic tariff method. Uncertainty management is required for the decentralized dynamic tariff

Uncertainty Management of Dynamic Tariff

Method for Congestion Management in

RTP

Distribution Networks method because the dynamic tariff is determined based on optimal day-ahead energy planning with forecasted parameters such as day-ahead energy prices and energy needs which might be different from the parameters used by aggregators

Long Term Incentives for Residential Customers Using Dynamic Tariff

RTP

This paper reviews several DDT schemes, including flat tariff, time-of-use, time-varying tariff, demand charge, and dynamic tariff, from the perspective of the long-term incentives.

Dynamic Power Tariff for Congestion Management in Distribution Networks

[22] RTP

This paper proposes a dynamic power tariff, a new concept for congestion management in distribution networks with high penetration of electric vehicles, and heat pumps.

Distributed Optimization-Based Dynamic Tariff for Congestion Management in Distribution

RTP Networks

Efficient Prediction of Dynamic Tariff in Smart Grid Using CGP Evolved Artificial Neural RTP Networks

[24]

RTP

\section{This paper proposes an optimization-based DDT method for congestion management in distribution networks with high penetration of electric vehicles and heat pumps.} which when incorporated in the smart grid can be quite beneficial in informing the user of the electricity price during the next hour. Two models have been evolved using the Neuro Evolutionary Cartesian Genetic Programming Evolved Artificial Neural Network algorithm to estimate the electricity prices for the next hour

This investigation presents a logical shifting algorithm for

Demand Response Program for Shiftable Modes in Variable Tariff Zones of an Utility
[25] RTP shiftable modes of operations of schedulable loads of users. In
this approach, we have considered a washing machine and dishwasher of residential shiftable loads due to its multiple modes of operation. A day-ahead zonal forecasting pricing data of New York City is taken from the website for the proposed algorithm illustration. 
Table 1. Cont.

\begin{tabular}{cccc}
\hline Title & Reference & DDT Type & Paper Scope
\end{tabular}

The results from a proof-of-concept study combining modern building automation systems (BAS) with DDTs are presented.

Building Control and Storage Management with Dynamic Tariffs for Shaping Demand Response

[26] RTP

\section{An Infrastructure of Dynamic Tariff}

Management and Demand Response applied to Smart Grids using Renewable Energy Resources and Energy Storage Systems

Real Time Emulation of Dynamic Tariff for Congestion Management in Distribution Networks

RTP The use of a building automation system that optimizes the electricity demand of a retail end-consumer while managing a local battery unit and respecting all comfort constraints, e.g., on room temperature, illuminance, and indoor air quality, is proposed. This paper presents a proposal for a management
infrastructure for DDTs and DR to support the consumer in an environment of smart grids, in the presence of renewable energy sources and energy storage systems.

This paper presents the real-time evaluation of the dynamic tariff method for alleviating congestion in a distribution network with high penetration of DERs. The dynamic tariff method is implemented in a real-time digital testing platform that emulates a real distribution network.

In this paper, a method for determining the tariff structures has been proposed, optimized for different load regimes. Daily

Dynamic Electricity Tariff Definition Based on Market Price, Consumption and Renewable RTP Generation Patterns
Sensitivity Analysis of Dynamic Tariff Method for Congestion Management in Distribution Networks
[30] RTP DDT structures were defined and proposed, on an hourly basis $24 \mathrm{~h}$ day-ahead from the characterization of the typical load profile, the value of the electricity market price, and considering the renewable energy production.

The dynamic tariff method is designed for the DSO to alleviate the congestions that might occur in a distribution network with high penetration of DERs. This paper conducts three case studies to demonstrate the impact of small and big changes of parameters on the line loading profiles and the effectiveness of the dynamic tariff method.

This paper proposes a comprehensive scheme for day-ahead congestion management of distribution networks with high penetration of DERs. In the proposed scheme, the DDT, network reconfiguration, and re-profiling products are integrated, which combines the advantages of these methods.

This paper proposes a tariff scheme as a benchmark for Towards Variable End-Consumer Electricity Tariffs Reflecting Marginal Costs: A Benchmark

RTP Tariff

Comprehensive Congestion Management for Reconfiguration, and Re-Profiling Product studying the DR of end-consumer. The tariff concept is applied to the situation in the city of Zurich, Switzerland, using time series of the Swiss EEX power market spot prices and Zurich's yearly electricity load profile.

Time-Optimized Dynamic Two-Step Tariffs for CHP Operation

ToU

This work proposes and improves a simplified dynamic two-step tariff for end-consumers based on the course of the EEX day-ahead electricity market.

Encouraged by the importance of finding a cost-efficient and

Dynamic Tariff Design for a Robust Smart Grid Concept: An Analysis of Global vs. Local robust approach for flexible appliances, a proposed structure Incentives

ToU

\footnotetext{
The Use of Dynamic Tariff by The Utilities to Counter act The Influence of Renewable Energy Sources
}

[35] ToU
ToU for a simplified dynamic tariff is analyzed in this study. The tariff is designed to enable selective shifting of load and decentralized generation.

In this research, a new DDT strategy was developed which will make electricity prices from the utility to be cheaper during the times when there are solar resources.

This paper presents a stochastic bottom-up model designed to

Modeling the Effects of Variable Tariffs on Domestic Electric Load Profiles by Use of Occupant Behavior Submodels

[36] ToU
predict the change in domestic electricity profile invoked by consumer reaction to electricity unit price, with submodels comprising user behavior, price response, and dependency between behavior and electric demand.

In this work, a new tool for the optimization of DDTs is

Effective Dynamic Tariffs for Price-Based

Demand Side Management with developed. This is based on a statistical analysis of the Grid-Connected PV Systems consumption profiles and optimization procedures, aiming to derive the most appropriate ToU tariffs.

Dynamic Network Tariffs: Are They the Most
Efficient Way to Match Peak Consumption and

Network Incremental Costs?
The purpose of this paper is to present the main results of the [38] CPP ongoing analysis of applying dynamic network access tariffs in Portugal. 
Table 1. Cont.

\begin{tabular}{|c|c|c|c|}
\hline Title & Reference & DDT Type & Paper Scope \\
\hline $\begin{array}{l}\text { Design of Grid Tariffs in Electricity Systems with } \\
\text { Variable Renewable Energy and Power to Heat }\end{array}$ & {$[39]$} & CPP & $\begin{array}{l}\text { This paper compares two different grid tariff designs that } \\
\text { facilitate more flexible energy demand of district heating } \\
\text { operators. }\end{array}$ \\
\hline $\begin{array}{l}\text { Implementation of dynamic Tariffs in the } \\
\text { Portuguese Eelectricity System-Preliminary } \\
\text { Results of a Cost-Benefit Analysis }\end{array}$ & {$[40]$} & $\begin{array}{l}\text { RTP, CPP, } \\
\quad \text { CPR }\end{array}$ & $\begin{array}{l}\text { This paper reports the results obtained regarding the } \\
\text { cost-benefit analysis. This analysis includes the identification of } \\
\text { critical hours during which dynamic tariffs can be activated }\end{array}$ \\
\hline Demand based Variable Electricity Tariff Meter & {$[41]$} & $\begin{array}{l}\text { Consumption } \\
\text { based ToU }\end{array}$ & $\begin{array}{l}\text { Introduces demand-based variable electricity tariff meter with } \\
\text { circuitry designed to tackle the problem of people consuming } \\
\text { electricity for only essential purposes pays the same as people } \\
\text { having luxurious consumption. }\end{array}$ \\
\hline $\begin{array}{l}\text { Variable Tariff Energy Meter with Automatic } \\
\text { Power Flow Control }\end{array}$ & {$[42]$} & $\begin{array}{l}\text { Consumption } \\
\text { based RTP }\end{array}$ & $\begin{array}{l}\text { This paper discusses a model and makes recommendations that } \\
\text { would be useful in the current Indian scenario. }\end{array}$ \\
\hline
\end{tabular}

\subsection{Categorization of DDTs in Literature}

According to [4], six attributes can define the tariff schemes and a designed dynamic tariff is recommended to consider these six attributes. Each attribute contains several sections that a dynamic tariff design can consider selecting (shown in Table 2). For example, in a dynamic tariff design, the energy price can vary either by 'time of use' and/or by the 'current load at the household level'. This 'time of use' and 'load level' belong to the attribute of 'Rationale'.

Table 2. Six attributes of dynamic tariffs (modified from [4]).

\begin{tabular}{|c|c|c|}
\hline Attribute & Explanation & Possible Sections in Each Attribute \\
\hline Rationale & $\begin{array}{l}\text { The price varies either by the time of } \\
\text { use and/or by the current load at the } \\
\text { household level. }\end{array}$ & $\begin{array}{l}\text { - } \quad \text { Time of use } \\
\text { - } \quad \text { Load level }\end{array}$ \\
\hline $\begin{array}{c}\text { Cost } \\
\text { components }\end{array}$ & $\begin{array}{l}\text { Reflect the value chain of energy, i.e., } \\
\text { generation, transmission, distribution, } \\
\text { and retail. }\end{array}$ & $\begin{array}{ll}\text { - } & \text { Generation } \\
\text { - } & \text { Transmission and Distributions } \\
\text { - } & \text { Other charges }\end{array}$ \\
\hline Cost drivers & $\begin{array}{l}\text { The factors driving the costs. The } \\
\text { independence of power and energy can } \\
\text { be, e.g., metering cost driven by the } \\
\text { number of customers connected }\end{array}$ & $\begin{array}{ll}- & \text { Power }(E U R / \mathrm{kW}) \\
\text { - } & \text { Energy }(\mathrm{EUR} / \mathrm{kWh}) \\
\text { - } & \text { Independent of power and } \\
\text { energy (EUR) }\end{array}$ \\
\hline Dynamics & $\begin{array}{l}\text { Can be the number of time blocks in a } \\
\text { day in the rate varies; } \\
\text { Can be expressed as the price update } \\
\text { frequency and the price spread, i.e., } \\
\text { price differentials between blocks }\end{array}$ & $\begin{array}{l}\text { - } \quad \text { Number of time blocks } \\
\text { - } \quad \text { Price update frequency } \\
\text { - } \quad \text { Price spread }\end{array}$ \\
\hline Events & $\begin{array}{l}\text { Defined by their duration, occurrence } \\
\text { (e.g., } 10 \text { times a year), and price spread. } \\
\text { Be implemented to incentivize } \\
\text { consumers to consume in events } \\
\text { having lower prices or avoid events } \\
\text { with high prices (e.g., in peak periods). }\end{array}$ & $\begin{array}{ll}\text { - } & \text { Duration } \\
\text { - } & \text { Occurrence } \\
\text { - } & \text { Price spread }\end{array}$ \\
\hline $\begin{array}{l}\text { Active } \\
\text { Demand }\end{array}$ & $\begin{array}{l}\text { Consumers imposing dynamic tariffs } \\
\text { may respond to price signals in a } \\
\text { manual or automated way }\end{array}$ & $\begin{array}{ll}\text { - } & \text { Manual } \\
\text { - } & \text { Automated }\end{array}$ \\
\hline
\end{tabular}


The attribute of cost components reflects the value chain of energy, i.e., generation, transmission, distribution, and retail. Since only distribution tariffs are considered in this paper, this attribute is neglected. According to the five attributes, the 29 relevant articles are analyzed and categorized.

\subsection{Literature Evaluation}

The literature evaluation aims to investigate the feasibilities of DDTs that can be implemented in an energy ecosystem. The feasibility evaluation is conducted with four dimensions: technical, economic, social, and regulatory.

\subsubsection{Technical Feasibility Evaluation}

The Technology Readiness Level (TRL) (described in Table A1 in Appendix A) [43] is used for the technical feasibility evaluation in this paper. TRL is originally designed by NASA for space exploration technologies, and TRLs measure the maturity level of a technology during its acquisition phase [44]. The TRL includes 9 levels, and the DDTs in the literature will be evaluated according to the description for each TRL level.

\subsubsection{Economic Feasibility Evaluation}

The majority of the literature regarding the economic feasibility evaluation focuses on the cost-benefit analysis of technologies or solutions, e.g., [45]. there is little literature for evaluating tariffs. According to the Cambridge dictionary, economic feasibility is 'the degree to which the economic advantages of something to be made, done, or achieved are greater than the economic costs'. Therefore, the cost can be the threshold for the economic feasibility of a DDT.

The economic feasibility evaluation in this paper is the monetary cost. This monetary cost is due to the acquisition of necessary devices or equipment for participation in a DDT program. The monetary participation cost scale has three level 1-3 is rated from low to high cost, that:

1 Low economic feasibility due to high cost to acquire new automatic solutions participation in the DDT program.

2 Medium cost for acquiring a device for participation in the DDT program, which typically for the continuous frequency measurement.

3 High economic feasibility due to little cost for participation in the DDT program requires no device or equipment.

\subsubsection{Social Feasibility Evaluation}

Distribution tariffs are part of the final electricity price that electricity consumers receive and DDTs aim to create incentives and motivate consumers to reduce or shift their energy consumption. Therefore, it is necessary to consider consumers' adoption of the DDT design. Various factors could influence consumers' adoption, and convenience is the most essential factor.

Therefore, this paper uses a user convenience level to evaluate the electricity consumers' response to the DDT price signals. There are three levels of user convenience:

1 Low convenience due to fully manual response with complex price signals (e.g., hourly prices)

2 Medium convenience due to fully manual response with easily understandable price signals (e.g., 2 price periods a day)

3 High convenience due to fully automatic response.

\subsubsection{Regulatory Feasibility Evaluation}

The regulatory feasibility in this paper is to evaluate whether the existing regulations allow the implementation of the State-of-the-Art solutions (DDTs in this paper), and if not, how likely the regulations will be realized in the future (regulatory readiness level). The 
Danish law of electricity supply [10] is applied in the paper with four levels of regulatory readiness:

0 The required regulation is impossible to happen

1 The required regulation might happen in the long term

2 The required regulation will happen in the medium term

3 The required regulation can happen in the short term

\section{Analysis and Evaluation of Dynamic Distribution Tariffs}

The electricity tariffs are usually part of the electricity bills to consumers and cover the total cost for producing and supplying electricity [46]. The tariffs for supplying electricity are also called grid tariffs, and there are usually two types of grid tariffs: transmission tariffs for paying the Transmission System Operator and distribution tariffs for paying the local DSOs.

The DDTs discussed in the 29 selected articles can be categorized into: RTP, ToU, CPP, and Consumption-based tariffs. RTP is the most popularly discussed DDT in the literature (19 out of 29 references), and two consumption-based tariffs (consumption-based RTP and consumption-based ToU) are discussed separately in two articles. Furthermore, 29 selected articles are analyzed in detail based on six attributes of dynamic tariffs proposed by [4], and 16 combinations are identified based on the similarities and differences of DDTs' attributes in the literature (shown in Table 3).

\subsection{Four Categories of Dynamic Distribution Tariffs}

\subsubsection{Real Time Pricing}

RTP (also called dynamic rate) aims to adapt consumption to external variables, such as spot prices, grid overload, and DERs, etc. The characteristics of RTP in the literature are shown in Table 4. The prices for RTP in the literature all vary by time of use. In general, the cost driver for RTP is energy [4], but two cost drivers (energy and power) are found in the literature, and energy is the most common cost driver, and power is discussed only in [22]. The price spread is not specific in RTP DDT as it often depends on grid conditions. ToU DDTs' price spread is often specific defined as a price ratio between the different price periods typically between $2-4$. Energy-based tariff is the most known price unit per consumed energy (DKK $/ \mathrm{kWh}$ ), whereas power is dependent on the size of the load as it is the price unit per power level per consumed energy (DKK $/ \mathrm{kW} / \mathrm{kWh}$ ). For instance, charging an EV with $11 \mathrm{~kW}$ for a short period would be more costly than charging with $3.7 \mathrm{~kW}$ in a longer period, even though the energy consumed is the same.

This paper finds that two types of price update frequencies (day-ahead forecast and the next hour forecast) have different objectives, and the day-ahead forecast is the most common in the literature. The main objective of the day-ahead forecast is to avoid grid congestions caused mainly by EV charging [14,16-23,28,30,31]. Different optimization methods and power flow calculations are discussed in the literature for congestion management. DR is an important objective discussed in the literature. For instance, for the demand side, peak loading reduction by automatically move load from appliances such as washing machine and dishwasher to low-cost time slots is discussed in [25], and a dynamic benchmark tariff design for assessing and evaluating the DR potential of price-responsive loads on the end-consumer side is proposed in [26,32]. The tariff is based on time-series of Swiss spot market prices (Swissix) as traded on the European Energy Exchange (EEX). 
Table 3. Dynamic Distribution Tariffs in literature.

\begin{tabular}{|c|c|c|c|c|c|c|c|c|c|c|c|}
\hline \multirow[b]{2}{*}{ No. } & \multirow[b]{2}{*}{ DDT Type } & \multirow[b]{2}{*}{ Rationale } & \multirow[b]{2}{*}{$\begin{array}{c}\text { Cost } \\
\text { Driver }\end{array}$} & \multicolumn{2}{|c|}{ Dynamics } & \multicolumn{2}{|c|}{ Events } & \multirow[b]{2}{*}{ Price Spread } & \multirow[b]{2}{*}{ Active Demand } & \multirow[b]{2}{*}{ Objective } & \multirow[b]{2}{*}{ Reference } \\
\hline & & & & Nr. of Time Blocks & $\begin{array}{l}\text { Price Update } \\
\text { Freq. }\end{array}$ & Duration & Occurrence & & & & \\
\hline \multirow{4}{*}{1} & \multirow{4}{*}{ RTP } & \multirow{4}{*}{$\begin{array}{c}\text { Time of } \\
\text { use }\end{array}$} & \multirow{4}{*}{ Energy } & \multirow{4}{*}{ 24/day (hourly) } & \multirow{4}{*}{$\begin{array}{l}1 / \text { day } \\
\text { (Day-ahead } \\
\text { forecast) }\end{array}$} & & & \multirow{4}{*}{$\begin{array}{c}\text { Considerable (dependent } \\
\text { on the external variables) } \\
\text { Often calculated by } \\
\text { power flow calculations } \\
\text { using different } \\
\text { optimization methods. }\end{array}$} & \multirow{4}{*}{ Automatic } & $\begin{array}{l}\text { The objective is to avoid grid } \\
\text { congestion-Congestion } \\
\text { management. }\end{array}$ & {$[14,16-21,23,28,30]$} \\
\hline & & & & & & & & & & $\begin{array}{l}\text { long-run incremental cost } \\
\text { pricing in network charges under } \\
\text { dynamic tariffs. The dynamic } \\
\text { tariff is not in focus. }\end{array}$ & [15] \\
\hline & & & & & & & & & & $\begin{array}{l}\text { used here as a dynamic } \\
\text { benchmark tariff for assessing } \\
\text { and evaluating the DR potential } \\
\text { of price-responsive loads on the } \\
\text { end-consumer side. It is based } \\
\text { on time-series of Swiss spot } \\
\text { market prices (Swissix) as traded } \\
\text { on the European Energy } \\
\text { Exchange (EEX) }\end{array}$ & {$[26,32]$} \\
\hline & & & & & & & & & & $\begin{array}{l}\text { Calculated based on load profile, } \\
\text { the value of electricity market } \\
\text { price, and renewable energy } \\
\text { production. Objective to } \\
\text { promoting generation and } \\
\text { consumption efficiency, while } \\
\text { improving players' benefits. }\end{array}$ & [29] \\
\hline 2 & RTP & $\begin{array}{l}\text { Time of } \\
\text { use }\end{array}$ & Power & 24/day (hourly) & $\begin{array}{l}1 / \text { day } \\
\text { (Day-ahead } \\
\text { forecast) }\end{array}$ & & & $\begin{array}{c}\text { Considerable (dependent } \\
\text { on the external variables) } \\
\text { Often calculated by } \\
\text { power flow calculations } \\
\text { using optimization } \\
\text { methods. }\end{array}$ & Automatic & $\begin{array}{l}\text { The objective is to avoid grid } \\
\text { congestion-Congestion } \\
\text { management. }\end{array}$ & [22] \\
\hline 3 & RTP & $\begin{array}{l}\text { Time of } \\
\text { use }\end{array}$ & Energy & 24/day (hourly) & $\begin{array}{l}24 / \text { day } \\
\text { (forecasts the } \\
\text { next hour) }\end{array}$ & & & $\begin{array}{l}\text { Considerable (dependent } \\
\text { on the external variables) } \\
\text { Calculated by Artificial } \\
\text { Neural Network }\end{array}$ & Not specified & $\begin{array}{l}\text { Demand side management in } \\
\text { smart grid environment } \\
\text { informing the user of the } \\
\text { electricity charge for the next } \\
\text { hour }\end{array}$ & [24] \\
\hline 4 & RTP & $\begin{array}{l}\text { Time of } \\
\text { use }\end{array}$ & Energy & 24/day (hourly) & $\begin{array}{l}1 / \text { day } \\
\text { (Day-ahead } \\
\text { forecast) }\end{array}$ & & & $\begin{array}{l}\text { Considerable (dependent } \\
\text { on the external variables) } \\
\text { Day-ahead market } \\
\text { Locational based } \\
\text { marginal pricing (LBMP) } \\
\text { in New York city }\end{array}$ & $\begin{array}{c}\text { Manual and/or } \\
\text { automation (washing } \\
\text { machines and } \\
\text { dishwasher are } \\
\text { shifted and could in } \\
\text { theory be automated. } \\
\text { It is not mentioned if } \\
\text { it is automatic or } \\
\text { manual) }\end{array}$ & $\begin{array}{l}\text { shifting the high-cost time slot of } \\
\text { appliance mode to a possible } \\
\text { low-cost time slot in the tariff } \\
\text { zone. }\end{array}$ & [25] \\
\hline
\end{tabular}


Table 3. Cont

\begin{tabular}{|c|c|c|c|c|c|c|c|c|c|c|c|}
\hline \multirow[b]{2}{*}{ No. } & \multirow[b]{2}{*}{ DDT Type } & \multirow[b]{2}{*}{ Rationale } & \multirow{2}{*}{$\begin{array}{c}\text { Cost } \\
\text { Driver }\end{array}$} & \multicolumn{2}{|c|}{ Dynamics } & \multicolumn{2}{|c|}{ Events } & \multirow[b]{2}{*}{ Price Spread } & \multirow[b]{2}{*}{ Active Demand } & \multirow[b]{2}{*}{ Objective } & \multirow[b]{2}{*}{ Reference } \\
\hline & & & & Nr. of Time Blocks & $\begin{array}{l}\text { Price Update } \\
\text { Freq. }\end{array}$ & Duration & Occurrence & & & & \\
\hline 5 & RTP & $\begin{array}{l}\text { Time of } \\
\text { use }\end{array}$ & Energy & 24/day (hourly) & $\begin{array}{l}1 / \text { day } \\
\text { (Day-ahead } \\
\text { forecast) }\end{array}$ & & & $\begin{array}{l}\text { Considerable (dependent } \\
\text { on the external variables) }\end{array}$ & Not specified & $\begin{array}{l}\text { Through a dynamic tariff and } \\
\text { DR management infrastructure, } \\
\text { utilities will be able to deliver } \\
\text { valuable consumer-focused } \\
\text { information. }\end{array}$ & [27] \\
\hline 6 & $\mathrm{ToU}$ & $\begin{array}{l}\text { Time of } \\
\text { Use }\end{array}$ & Energy & $2 /$ day & $\begin{array}{l}\text { Not specified } \\
\text { (assumed to be } \\
1 / \text { year) }\end{array}$ & & & $\begin{array}{l}\text { Price ratio of high to low } \\
\text { is } 2.55\end{array}$ & Manual & $\begin{array}{l}\text { Shifting electricity demand for } \\
\text { analyzing demand side } \\
\text { management potential. }\end{array}$ & [36] \\
\hline 8 & $\mathrm{ToU}$ & $\begin{array}{l}\text { Time of } \\
\text { use }\end{array}$ & Energy & $2 /$ day & Not specified & & & Not specified & Not specified & Incentivize load shifting. & {$[33,34]$} \\
\hline 9 & $\mathrm{ToU}$ & $\begin{array}{l}\text { Time of } \\
\text { use }\end{array}$ & Energy & $2 /$ day & $\begin{array}{c}2 / \text { year } \\
\text { (winter/summer } \\
\text { season) }\end{array}$ & & & Not specified & Not specified & $\begin{array}{l}17 \mathrm{~h} \text { winter, } 3.5 \mathrm{~h} \text { high tariffs in } \\
\text { summer. }\end{array}$ & [33] \\
\hline 10 & $\mathrm{ToU}$ & $\begin{array}{l}\text { Time of } \\
\text { use }\end{array}$ & Energy & $2 /$ day & $\begin{array}{c}12 / \text { year } \\
\text { (monthly based) }\end{array}$ & & & Not specified & Not specified & $\begin{array}{l}\text { See reference for number of high } \\
\text { tariff prices in each month. }\end{array}$ & [33] \\
\hline 11 & $\mathrm{ToU}$ & $\begin{array}{l}\text { Time of } \\
\text { use }\end{array}$ & Energy & 3/day & $\begin{array}{l}\text { 2/year (high } \\
\text { demand period } \\
\text { June-August } \\
\text { and low } \\
\text { demand period } \\
\text { September-May) }\end{array}$ & & & $\begin{array}{l}\text { Ratio of about } 4.6 \\
\text { between the high and low } \\
\text { price in high demand } \\
\text { season and } 2.3 \text { in low } \\
\text { demand season. }\end{array}$ & Manual & $\begin{array}{l}\text { Incentivize consumers to } \\
\text { consume electricity in periods } \\
\text { with high electricity production } \\
\text { from PVs. }\end{array}$ & [35] \\
\hline 12 & $\mathrm{ToU}$ & $\begin{array}{l}\text { Time of } \\
\text { use }\end{array}$ & Energy & $\begin{array}{c}\text { Optimization of } \\
\text { blocks and time of } \\
\text { blocks based on PV } \\
\text { production and } \\
\text { consumption as } \\
\text { input }\end{array}$ & Not specified & & & $\begin{array}{l}\text { A ratio of about } 2 \\
\text { between highest and } \\
\text { lowest price. }\end{array}$ & Manual & $\begin{array}{l}\text { Develop optimal demand-side } \\
\text { management using ToU dynamic } \\
\text { tariffs (includes PV production) }\end{array}$ & [37] \\
\hline 13 & СРP & $\begin{array}{l}\text { Time of } \\
\text { use }\end{array}$ & Energy & & & $\begin{array}{l}\text { Last up to } 8 \\
\mathrm{~h}\end{array}$ & $\begin{array}{l}\text { Consumers } \\
\text { are warned } \\
1-2 \text { days prior } \\
\text { to the event. }\end{array}$ & Not specified & Manual & $\begin{array}{l}\text { A pilot project testing dynamic } \\
\text { tariffs on the network } \\
\text { component. }\end{array}$ & [38] \\
\hline 14 & СРP & $\begin{array}{l}\text { Time of } \\
\text { use }\end{array}$ & Energy & & & $\begin{array}{l}\text { Reflect the } \\
\text { local grid } \\
\text { capacity } \\
\text { constraints }\end{array}$ & $\begin{array}{l}\text { When the load } \\
\text { on the local } \\
\text { grid is critical. } \\
\text { Not specified } \\
\text { further. }\end{array}$ & Not specified & Not specified & $\begin{array}{l}\text { Improve business case for power } \\
\text { to heat technologies and to } \\
\text { induce more renewable energy } \\
\text { in the system }\end{array}$ & [39] \\
\hline
\end{tabular}


Table 3. Cont

\begin{tabular}{|c|c|c|c|c|c|c|c|c|c|c|c|}
\hline \multirow[b]{2}{*}{ No. } & \multirow[b]{2}{*}{ DDT Type } & \multirow[b]{2}{*}{ Rationale } & \multirow[b]{2}{*}{$\begin{array}{l}\text { Cost } \\
\text { Driver }\end{array}$} & \multicolumn{2}{|c|}{ Dynamics } & \multicolumn{2}{|c|}{ Events } & \multirow[b]{2}{*}{ Price Spread } & \multirow[b]{2}{*}{ Active Demand } & \multirow[b]{2}{*}{ Objective } & \multirow[b]{2}{*}{ Reference } \\
\hline & & & & Nr. of Time Blocks & $\begin{array}{l}\text { Price Update } \\
\text { Freq. }\end{array}$ & Duration & Occurrence & & & & \\
\hline 15 & $\begin{array}{c}\text { Consumption } \\
\text { based ToU }\end{array}$ & $\begin{array}{l}\text { Time of } \\
\text { use and } \\
\text { load level }\end{array}$ & Energy & $\begin{array}{c}5 / \text { day and } 1 \\
\text { threshold load level } \\
\text { of more than } 5 \text { units } \\
\text { of power } \\
\text { consumption ( } 5 \text { units } \\
\text { is estimated to cover } \\
\text { the essential devices, } \\
\text { hence only luxury } \\
\text { devices penalized) }\end{array}$ & Not specified & & & $\begin{array}{l}\text { The ratio of } 1.6 \text { between } \\
\text { lowest and highest base } \\
\text { rates. Crossing the } \\
\text { threshold increases the } \\
\text { price by either } 40,50,60, \\
\text { or } 70 \% .\end{array}$ & Not specified & $\begin{array}{l}\text { Tackle the problem that } \\
\text { consumers with only essential } \\
\text { consumption purposes pay the } \\
\text { same as consumers with luxury } \\
\text { consumption. }\end{array}$ & [41] \\
\hline 16 & $\begin{array}{l}\text { Consumption } \\
\text { based RTP }\end{array}$ & $\begin{array}{l}\text { Time of } \\
\text { use and } \\
\text { load level }\end{array}$ & Energy & Not specified & Not specified & & & $\begin{array}{l}\text { The suggested tariff } \\
\text { structure allows a defined } \\
\text { limit. Consuming more } \\
\text { than the limit will } \\
\text { increase the price by a } \\
\text { ratio of } 5 .\end{array}$ & Not specified & $\begin{array}{l}\text { Cost }=(50 / f) * \text { Tariff } * \text { Energy. } \\
\text { Where } 50 \text { is the frequency level } \\
\text { in India (case) and f is the } \\
\text { current frequency. Motivating } \\
\text { consumers to consume more if } \\
\text { the frequency is higher (hence, } \\
\text { lower prices) and vice versa. }\end{array}$ & [42] \\
\hline
\end{tabular}


Table 4. The characteristics of RTP in the literature.

\begin{tabular}{|c|c|}
\hline DDT Type & RTP \\
\hline Rationale & Time of Use \\
\hline Cost driver & $\begin{array}{l}\text { - } \quad \text { Energy (is the most known when you pay per } \mathrm{kWh} \text { ) } \\
\text { Power (is dependent on the size of the load as it is paid by the } \\
\mathrm{kW} / \mathrm{kWh} \text { ) }\end{array}$ \\
\hline No. of time blocks & 24/day (hourly) \\
\hline Price update freq. & $\begin{array}{l}\text { - } \quad \text { Day-ahead forecast } \\
\text { - } \quad 24 / \text { day (forecasts the next hour) }\end{array}$ \\
\hline Price spread & $\begin{array}{l}\text { - } \quad \text { Considerable (dependent on the external variables) } \\
\text { - } \quad \text { Calculated by power flow calculations using different } \\
\text { optimization methods. } \\
\text { - } \quad \text { Day-ahead market Locational based marginal pricing (LBMP) in } \\
\text { New York city } \\
\text { - Calculated by artificial neural network (forecasts the next hour) }\end{array}$ \\
\hline Active demand & $\begin{array}{l}\text { - } \quad \text { Automatic } \\
\text { Manual and/or automation (e.g., washing machines and } \\
\text { dishwasher are time-shifted) }\end{array}$ \\
\hline
\end{tabular}

Meanwhile, the day-ahead forecast with the grid perspective is also discussed in the literature. In [27], dynamic tariff and DR management infrastructure are used by utilities to deliver valuable consumer-focused information, and an economically efficient approach for pricing network charges is discussed in [15] to identify the impacts of demand flexibility on the long-run incremental cost method. Furthermore, in [29], DDT is used to promote generation and consumption efficiency while improving players' benefits. The tariff is calculated based on load profile, the value of electricity market price, and renewable energy production.

Different from other literature, ref. [24] discusses the hourly forecasting, and proposes a CGP (Cartesian Genetic Programming) evolved artificial neural network algorithm to estimate the electricity prices for the next hour, and the algorithm is used for demand side management.

\subsubsection{Time-of-Use Pricing}

ToU pricing is to change end-users' routine behaviors. The main objective of using ToU pricing to provide incentives to local consumers and producers for load shifting. Reference [33] uses different ToU schemes to identify the best scheme considering the tariff complexity against flexibility potential and financial gains for the end-user. Reference [36] analyzes the demand-side management potential using ToU tariffs. Reference [21] incentivizes the end-users to shift demand using only economic benefits for the user. This is done by designing the scheme in a way that the users who do not change their consumption behavior will have the same costs as if they had a flat rate. In [35], ToU scheme is designed to shift consumption to periods with high electricity production from PVs. The objective of [37] is to enable high penetration of renewable energy sources by use of ToU tariffs. Reference [37] develops a tool for optimizing the ToU DDT identifying optimal periods and tariff rates.

The characteristics of ToU in the literature are shown in Table 5 . Two times per day is the most common time block used in $[21,33,34,36]$, and the price update frequencies are different, e.g., 1 time per year in [21], 2 times per year (winter/summer season) in [33], and monthly based in [33]. In [35], there are three time blocks in the ToU pricing and the price updates twice per year with the high demand period of June to August and the low demand period of September to May. 
Table 5. The characteristics of ToU in the literature.

\begin{tabular}{cl}
\hline Rationale & \multicolumn{1}{c}{ Time of Use } \\
\hline Cost Driver & \multicolumn{1}{c}{ Energy } \\
\hline \multirow{3}{*}{ Number of time blocks } & 2/day \\
& 2/day (higher prices in peak period) \\
& 3/day \\
& Blocks and time of blocks are found using optimization \\
& taken PV production and consumption as input \\
\hline Price update freq. & 1/year \\
& 2/year (winter/summer season) \\
& 2/year (high demand period June-August and low demand \\
& period September-May) \\
& 12/year (monthly based) \\
\hline Price spread & Price ratio of high to low is 2.55 \\
& Total cost is in theory the same as a flat rate. \\
& Ratio of about 4.6 between the high and low price in high \\
& demand season and 2.3 in low demand season. \\
& A ratio of about 2 between highest and lowest price. \\
\hline Active demand & \multicolumn{1}{c}{ Manual } \\
\hline
\end{tabular}

Contrastingly, optimal demand-side management using ToU dynamic tariffs (includes PV production) is discussed in [37]. The blocks and times of blocks are optimized based on PV production and consumption, therefore, there is no fixed number of time locks. With this method, the price spread is with a ratio of about 2 between the highest and lowest prices.

\subsubsection{Critical Peak Pricing}

CPP and Critical Peak Rebate (CPR) are two types of Critical Consumption Pricing (CCP). CPP aims to reduce critical peak demand that is usually to avoid grid overload. To avoid grid overload, CPP increases the electricity prices for the peak hours much higher than the regular price. CPR aims to increase demand when there is abundant electricity in the grid, e.g., high renewable non-dispatchable electricity production.

CPP is not popularly discussed as RTP and ToU, and only discussed in two articles. Ref. [38] presents a pilot project that tests CPP DDT on the network component. the CPP events last up to $8 \mathrm{~h}$ and consumers are warned 1-2 days prior to the event. The CPP discussed in [39] is to improve the business case for power to heat technologies and induce more renewable energy in the system. The CPP events in [39] are designed to reflect the local grid capacity constraints and are triggered when the local grid load is critical.

\subsubsection{Consumption-Based ToU and RTP}

The goals of consumption-based DDTs are energy-saving, a general load reduction, and consolidation at a certain load level [4]. Two consumption-based DDT are discussed in the literature: Consumption-based ToU and consumption-based RTP. The main objective of the consumption-based ToU is to tackle the problem that consumers with only essential consumption purposes pay the same as consumers with luxury consumption [41]. Comparatively, consumption-based RTP suggested by [42] aims to motivate consumers to consume more if the frequency is higher (hence, lower prices) and vice versa, and the RTP changes depend on the frequency based on the Equation (1).

$$
\text { Dynamic Tariff }=(50 / f) \times \mathrm{r}_{\text {Tariff }} \times \text { Energy }
$$

where $f$ is the frequency in the grid and 50 is due to the Indian grid is operating with a frequency of $50 \mathrm{~Hz}$. $\mathrm{r}_{\text {Tariff }}$ is the tariff rate and Energy is the consumed energy. If a certain 
threshold is reached then the price is multiplied by 5 (price spread ratio of 5), hence adding the consumption-based aspect to the RTP tariff.

The number of time blocks per day in the consumption-based DDTs is usually based on the share of consumption or the overall currently used load. For instance, in [41], there are 5 time blocks per day and 1 threshold load level of more than 5 units of power consumption ( 5 units is estimated to cover the essential devices, hence only luxury devices are penalized). The price spread has a ratio of 1.6 between the lowest and highest price periods, and when exceeding the threshold, a price spread ratio of 1.4-1.7 between the regular period price and the new penalized price.

\subsection{Technical Feasibility of DDTs in Literature}

The TRLs of the DDTs in the literature are shown in Table 6. All the RTP in the literature can be defined as at TRL 3- Experimental proof-of-concept because the proof-ofconcept through simulation is conducted. However, a complex calculation of an hourly day-ahead DDT that can reflect forecasted operation costs and forecasts the next hour's price during the current hour is not yet technically validated in lab or relevant environment. For instance, DDT number 1 (from Table 3) uses a day-ahead DDT calculation based on expected consumption with differentiated prices dependent on the grid locations, but this DDT has not been implemented. Meanwhile, ref. [24] proofs the concept of DDT number 4 through simulation using data for New York City.

Table 6. Technology readiness level of identified DDTs.

\begin{tabular}{|c|c|c|c|}
\hline DDT Type & $\begin{array}{l}\text { DDT Number } \\
\text { from Table } 3\end{array}$ & TRL & Explanation \\
\hline RTP & $1,2,3,4,5$ & 3 & $\begin{array}{l}\text { Proof-of-concept through } \\
\text { simulation is conducted. }\end{array}$ \\
\hline ToU & $6,7,8,9,10,11,12$ & 9 & $\begin{array}{l}\text { A typical ToU pricing scheme is } \\
\text { seen in operation today. }\end{array}$ \\
\hline $\mathrm{CPP}$ & 13,14 & 9 & $\begin{array}{l}\text { A typical CPP pricing scheme is } \\
\text { seen in operation today. }\end{array}$ \\
\hline Consumption based ToU & 15 & 3 & Not yet implemented in practice. \\
\hline Consumption based RTP & 16 & 3 & Not yet implemented in practice. \\
\hline
\end{tabular}

All ToU DDTs from the literature have a TRL 9 as all of the ToU schemes are reflecting ToU schemes already implemented in the real world today. There might be differences in the ratio and time blocks compared to what is implemented today, but all DDTs in the literature can be implemented today. For instance, DDT number 6 uses a ToU scheme with two price periods a day and the price spread is of ratio 2.55 between lowest and highest price.

CPP DDTs discussed in the two literature have TRL 9. For instance, the CPP DDTs are implemented for small, medium, and large business customers with $12 \mathrm{CPP}$ events a year in [39], and a CPP pilot project is conducted in [38].

Both consumption-based DDTs (the ToU combined with a consumption-based pricing scheme [41] and the RTP combined with a consumption-based pricing scheme [42]) are yet not implemented in practice and not validated in lab or relevant environment bringing the DDT on a TRL 3. Reference [41] proposes a concept formulation of the hardware and proofs the concept through real time calculations. The calculations are assumed to be done by a model. Reference [42] proposes a model/program for the consumption-based RTP DDT which shows the proof-of-concept.

\subsection{Economic and Social Feasibility of DDTs in Literature}

Each DDT is evaluated based on the users' actions, and the economic feasibility (participation monetary costs) and the social feasibility (user convenience levels) are identified based on the evaluation results (shown in Table 7). The participation cost is rated from 1 to 
3 ( 1 is low cost and 3 is the high cost) and the user convenience levels (1-3) describe the convenience of end-users for responding to the DDT price signals.

Table 7. Economic and social feasibilities for each DDT.

\begin{tabular}{|c|c|c|c|c|}
\hline DDT Type & $\begin{array}{l}\text { DDT Number } \\
\text { from Table } 3\end{array}$ & End-User's Actions & $\begin{array}{l}\text { Economic Feasibility } \\
\text { (Participation } \\
\text { Monetary Cost Level) }\end{array}$ & $\begin{array}{l}\text { Social Feasibility } \\
\text { (User Convenience } \\
\text { Level) }\end{array}$ \\
\hline \multirow{5}{*}{ RTP } & 1 & $\begin{array}{l}\text { Users have to acquire automatic devices. Therefore, } \\
\text { home appliances and other devices can be controlled } \\
\text { automatically as a response to DDT signals. Afterward, } \\
\text { the acquired devices can automatically consume } \\
\text { electricity as cheaply as possible. }\end{array}$ & 1 & 3 \\
\hline & 2 & $\begin{array}{l}\text { This DDT uses automatic response but has power as a } \\
\text { cost driver that it makes more inconvenient for } \\
\text { end-users to decide when to and how much to } \\
\text { consume. }\end{array}$ & 1 & 3 \\
\hline & 3 & $\begin{array}{l}\text { This solution calculates the next hour's price in the } \\
\text { given hour and does not mention if the users respond } \\
\text { automatically or manually to the DDT. However, either } \\
\text { automatic or manual, this solution is very inconvenient } \\
\text { as even automatic solutions will have difficulties } \\
\text { prioritizing consumption in hours which is not known. }\end{array}$ & 1 & 1 \\
\hline & 4 & $\begin{array}{l}\text { Due to the unclear description in the literature, this } \\
\text { solution is assumed to have a manual response to the } \\
\text { DDT that users have to check the DDT every day and } \\
\text { shift their use of washing machines and dishwashers. }\end{array}$ & 3 & 1 \\
\hline & 5 & $\begin{array}{l}\text { Due to the day-ahead RTP scheme, users have to check } \\
\text { prices at least once a day. }\end{array}$ & 3 & 1 \\
\hline \multirow{4}{*}{ ToU } & $6,7,8,9$ & $\begin{array}{l}\text { Since only } 2 \text { ToU periods are chosen per day, users can } \\
\text { easily choose to consume or not in the high-price } \\
\text { periods }\end{array}$ & 3 & 3 \\
\hline & 10 & $\begin{array}{l}\text { Prices are updated once each month and it is easy for } \\
\text { users to understand only two price levels a day. }\end{array}$ & 3 & 3 \\
\hline & 11 & $\begin{array}{l}\text { Three price levels in one day are still considered as } \\
\text { easily manageable for users }\end{array}$ & 3 & 3 \\
\hline & 12 & $\begin{array}{l}\text { This DDT calculates the ToU time blocks and their } \\
\text { length based on PV production and consumption data. } \\
\text { It is assumed to be done once a year based on the } \\
\text { statistical data, resulting in a regular ToU tariff for users } \\
\text { that the time blocks might be too many. }\end{array}$ & 3 & 2 \\
\hline & 13 & Users are warned 1-2 days before the CPP event. & 3 & 3 \\
\hline $\mathrm{CPP}$ & 14 & $\begin{array}{l}\text { Users have to take fast load shifting/reduction actions } \\
\text { as the CPP event in this DDT is based on the criticality } \\
\text { of the local grid. }\end{array}$ & 3 & 1 \\
\hline $\begin{array}{l}\text { Consumption- } \\
\text { based } \\
\text { ToU }\end{array}$ & 15 & $\begin{array}{l}\text { No actions are needed for users besides essential } \\
\text { consumption. End-users with luxury consumption (e.g., } \\
\text { air conditioning) should take shift load according to the } \\
\text { ToU scheme. }\end{array}$ & 3 & 3 \\
\hline $\begin{array}{l}\text { Consumption- } \\
\text { based } \\
\text { RTP }\end{array}$ & 16 & $\begin{array}{l}\text { Action based on the system's frequency and keeping } \\
\text { the consumption below a limit }\end{array}$ & 2 & 1 \\
\hline
\end{tabular}

For instance, for DDT number 1, users have to acquire automatic devices that home appliances and other devices can be controlled automatically as a response to DDT signals. Afterward, the devices can automatically consume electricity as cheaply as possible. Therefore, the user convenience level is 3 , and participation cost is high (3) due to the device acquisition.

In general, automatic consumer response requirement high investment costs to enable devices and systems to respond automatically. Therefore, RTP without automatic response solutions is rated 1- low convenience level as the user has to check the RTP tariff and 
manually react. ToU DDTs with less than 4 periods a day with a price update of a month or more are estimated to have high convenience as it is easy for users to understand and respond to different price periods.

\subsection{Regulatory Feasibility of DDTs in Literature}

The $\$ 73$ in the Danish law of electricity supply [10] and article 18 in the European Union's electricity ordinance [47] are the most important laws to follow when designing a DDT in Denmark. The essential part of these laws is that the tariff has to be:

- Reasonable

- Non-discriminating

- Objective

- $\quad$ Reflecting the true costs

- Transparent

- Take grid security and flexibility into consideration

The regulatory readiness levels for DDTs in the literature (shown in Table 8) are identified based on the comparison of the realization requirements for DDTs in the literature and the Danish regulation requirements (bullet-points) above. Table 8 shows that all types of ToU DDTs have a regulatory readiness level of 3 (can happen in the short term) and are potentially implemented in Denmark.

Table 8. Required regulations for each relevant DDT scheme.

\begin{tabular}{|c|c|c|c|}
\hline DDT Type & DDT Number & Required Regulations & $\begin{array}{c}\text { Regulatory } \\
\text { Readiness Level }\end{array}$ \\
\hline \multirow{4}{*}{ RTP } & 1 & $\begin{array}{l}\text { This DDT scheme discriminates as the tariff is based on grid congestions in grid } \\
\text { nodes. This means that neighbors theoretically pay different prices for electricity } \\
\text { depending on the location in the grid. Price differentiating based on geographical } \\
\text { delimitation is according to } § 73 \text { in the Danish law of electricity supply only allowed } \\
\text { in special cases. }\end{array}$ & 1 \\
\hline & 2 & $\begin{array}{l}\text { Power-dependent prices are a different way of settling the used electricity and are } \\
\text { following the regulations. However, besides the power-dependent price, the scheme } \\
\text { is similar to DDT number } 1 \text { and is rated the same. }\end{array}$ & 1 \\
\hline & 3 & $\begin{array}{l}\text { The tariff for the next hour in this RTP scheme determines this DDT is not } \\
\text { transparent. It will not happen at all because even the automatic response cannot } \\
\text { operate efficiently with only the next hour's information. }\end{array}$ & 0 \\
\hline & 4,5 & $\begin{array}{l}\text { The transparency of this RTP scheme is determined by whether the day-ahead prices } \\
\text { are already introduced from the electricity spot price. However, it is not considered } \\
\text { to be transparent to end-users. Therefore, it doesn't follow the legal requirement. }\end{array}$ & 1 \\
\hline \multirow{4}{*}{ ToU } & 6 & $\begin{array}{l}\text { This ToU DDT scheme reflects the true cost, as it uses a price ratio of } 2.55 \text {. The price } \\
\text { ratio is assumed to be adapted to the individual grid. }\end{array}$ & 3 \\
\hline & 7 & $\begin{array}{l}\text { As the price ratio for this ToU scheme reflects the flat rate if the consumption } \\
\text { continues as normal, the realization level is high. }\end{array}$ & 3 \\
\hline & $8,9,10,11$ & This ToU DDT scheme does not conflict with the regulations. & 3 \\
\hline & 12 & $\begin{array}{l}\text { It is assumed that the optimization in this ToU DDT scheme decides the number of } \\
\text { time blocks and the length and is considered to match the transparency requirement } \\
\text { (i.e., not too many time blocks). }\end{array}$ & 3 \\
\hline \multirow{2}{*}{$\mathrm{CPP}$} & 13 & $\begin{array}{l}\text { If the price of the CPP event reflects true costs, it follows the regulations that give a } \\
\text { warning 1-2 days. Therefore, this CPP is considered transparent. }\end{array}$ & 3 \\
\hline & 14 & $\begin{array}{l}\text { The CPP events occur when grid conditions are critical without warning the users in } \\
\text { advance. Hence, it is not considered transparent and is given a low regulatory } \\
\text { readiness level. }\end{array}$ & 1 \\
\hline
\end{tabular}


Table 8. Cont.

\begin{tabular}{cccc}
\hline DDT Type & DDT Number & Required Regulations & $\begin{array}{c}\text { Regulatory } \\
\text { Readiness Level }\end{array}$ \\
\hline $\begin{array}{c}\text { Consumption- } \\
\text { based } \\
\text { ToU }\end{array}$ & 15 & $\begin{array}{l}\text { This DDT discriminates the users with more than only essential appliances. This is } \\
\text { not expected to happen in Denmark. }\end{array}$ & 0 \\
\hline $\begin{array}{c}\text { Consumption- } \\
\text { based } \\
\text { RTP }\end{array}$ & 16 & $\begin{array}{l}\text { This DDT is not transparent as the tariff is dependent on the system frequency in } \\
\text { real-time. }\end{array}$ & 1 \\
\hline
\end{tabular}

A CPP introduced in [38] also have a regulatory readiness level of 3, because this $\mathrm{CPP}$ is considered transparent (it follows the regulations as a warning 1-2 days before the event) and reflects true costs (if the price of the CPP event reflects true costs). Other DDTs in the literature have low regulatory readiness levels which indicate the difficulties be implemented in Denmark.

\section{Discussion}

The feasibility evaluation method for DDTs includes the technological, economic, social and regulatory dimensions, and each dimension includes several levels (as shown in Table 9). Table 9 shows that, for each dimension, a higher level/scale means higher feasibility this DDT has.

Table 9. The technological, economic, social, and regulatory feasibility evaluation method for dynamic distribution tariffs.

\begin{tabular}{|c|c|c|c|}
\hline Dimension & Explanation & & Feasibility Level \\
\hline Technical feasibility & $\begin{array}{l}\text { Technology Readiness Level } \\
\text { (TRL) }\end{array}$ & $\begin{array}{l}1 \\
2 \\
3 \\
4 \\
5 \\
6 \\
7 \\
8 \\
9\end{array}$ & $\begin{array}{l}\text { Basic principles observed } \\
\text { Technology concept formulated } \\
\text { Experimental proof of concept } \\
\text { Technology validated in lab } \\
\text { Technology validated in a relevant environment } \\
\text { Technology pilot demonstrated in a relevant environment } \\
\text { System prototype demonstration in an operational environment } \\
\text { System complete and qualified } \\
\text { The actual system is proven in an operational environment }\end{array}$ \\
\hline Economic feasibility & $\begin{array}{l}\text { Monetary cost is due to the } \\
\text { acquisition of necessary } \\
\text { devices or equipment for } \\
\text { participation in a DDT } \\
\text { program }\end{array}$ & 3 & $\begin{array}{l}\text { Low economic feasibility due to high cost to acquire new automatic } \\
\text { solutions participation in the DDT program. } \\
\text { Medium cost for acquiring a device for participation in the DDT } \\
\text { program, which typically for the continuous frequency measurement. } \\
\text { High economic feasibility due to little cost for participation in the DDT } \\
\text { program requires no device or equipment. }\end{array}$ \\
\hline Social feasibility & $\begin{array}{l}\text { user convenience for } \\
\text { responding to DDT price } \\
\text { signals. }\end{array}$ & $\begin{array}{l}2 \\
3\end{array}$ & $\begin{array}{l}\text { Low convenience due to fully manual response with complex price } \\
\text { signals } \\
\text { Medium convenience due to fully manual response with easily } \\
\text { understandable price signals } \\
\text { High convenience due to fully automatic response. }\end{array}$ \\
\hline Regulatory feasibility & $\begin{array}{l}\text { Regulatory readiness for } \\
\text { DDT implementation }\end{array}$ & $\begin{array}{l}0 \\
1 \\
2 \\
3\end{array}$ & $\begin{array}{l}\text { The required regulation is impossible to happen } \\
\text { The required regulation might happen in the long term } \\
\text { The required regulation will happen in the medium term } \\
\text { The required regulation can happen in the short term }\end{array}$ \\
\hline
\end{tabular}

The evaluation results of the DDTs in the literature are shown in Table 10. In Table 10, the column of total value (equals to the sum of the scores for all four feasibility dimensions) indicates the overall feasibility score for each DDT. Therefore, all six ToU get the highest score (18), and one CPP also gets 18. 
Table 10. Overview of the evaluation grades, all above the bold line are top graded in all categories.

\begin{tabular}{|c|c|c|c|c|c|c|}
\hline $\begin{array}{c}\text { DDT } \\
\text { Number }\end{array}$ & DDT Type & $\begin{array}{c}\text { Technology } \\
\text { Readiness } \\
\text { Level }\end{array}$ & $\begin{array}{l}\text { Economic } \\
\text { Feasibility }\end{array}$ & $\begin{array}{c}\text { Social } \\
\text { Feasibility }\end{array}$ & $\begin{array}{c}\text { Regulatory } \\
\text { Readiness } \\
\text { Level }\end{array}$ & Total Value \\
\hline 6 & ToU & 9 & 3 & 3 & 3 & 18 \\
\hline 7 & ToU & 9 & 3 & 3 & 3 & 18 \\
\hline 8 & ToU & 9 & 3 & 3 & 3 & 18 \\
\hline 9 & ToU & 9 & 3 & 3 & 3 & 18 \\
\hline 10 & ToU & 9 & 3 & 3 & 3 & 18 \\
\hline 11 & ToU & 9 & 3 & 3 & 3 & 18 \\
\hline 13 & $\mathrm{CPP}$ & 9 & 3 & 3 & 3 & 18 \\
\hline 12 & ToU & 9 & 3 & 2 & 3 & 17 \\
\hline 14 & $\mathrm{CPP}$ & 9 & 3 & 1 & 1 & 14 \\
\hline 1 & RTP & 3 & 1 & 3 & 1 & 8 \\
\hline 15 & $\begin{array}{l}\text { Consumption } \\
\text { based ToU }\end{array}$ & 3 & 3 & 3 & 0 & 9 \\
\hline 2 & RTP & 3 & 1 & 3 & 1 & 8 \\
\hline 4 & RTP & 3 & 3 & 1 & 1 & 8 \\
\hline 5 & RTP & 3 & 3 & 1 & 1 & 8 \\
\hline 16 & $\begin{array}{l}\text { Consumption } \\
\text { based RTP }\end{array}$ & 3 & 2 & 1 & 1 & 7 \\
\hline 3 & RTP & 3 & 1 & 1 & 0 & 5 \\
\hline
\end{tabular}

Note: the total value $=$ SUM of scores for all four feasibility dimensions.

Therefore, according to the evaluation results, the most suitable DDT for implementation in Denmark. The ToU gets the highest score because it requires simple time schedules with differentiated tariffs. It is easy to understand for consumers and relatively easy to implement by the DSOs. The CPP (DDT No. 13) gets the highest score because it only requires a 1-2 day-ahead warning and it is easy for consumers to react to the events and the DSOs to implement compared to other CPPs.

Although the evaluation results in Table 10 show that the ToU pricing scheme has the most potentials to be implemented in Denmark, to realize and implement ToU into the Danish market, the ToU prices are required to reflect the real costs. Meanwhile, although the CPP DDT number 13 has the highest score in all evaluation categories, a qualified calculation of a true cost is needed to implement this CCP in Denmark, but such calculations are not available.

The RTP day-ahead scheme for congestion management has been the most discussed in the literature. However, the evaluation results show that it will not be realized in Denmark in the short term because it calculates DDT in each node in the grid. Therefore, two neighboring houses potentially can have different DDT prices which is difficult to be implemented in Denmark under the current or future regulations. Another main barrier for the DDTs to be implemented is due to the requirement of transparency to users.

\section{Dynamic Distribution Tariff in Denmark}

The developed feasibility evaluation method has reviewed dynamic distribution tariffs in the literature, and ToU is the most feasible DDT according to the evaluation result. However, there is much information in detail missing in the literature due to each article's scope. Therefore, to verify the evaluation method, this paper uses a proposal for the future distribution tariff in Denmark and a Danish DSO for the investigation.

In Denmark, the DSO's electricity customers are divided into segments based on the grid-level connection (shown in Table 11). Since 2015, Denmark has implemented a tariff model called "tarifmodel 2.0" (DDT 2.0) which has replaced the regular flat rate tariff and created incentives to shift consumption from peak hours. For example, for households (C-customers who are charged at the $0.4 \mathrm{kV}$ level), the DDT 2.0 introduces a high-price tariff in $3 \mathrm{~h}$ from 5 to $8 \mathrm{PM}$ during the winter period [48]. 
Table 11. Customer segmentation based on the grid-level connection [49].

\begin{tabular}{cc}
\hline Customer Segment & Grid-Level Connection \\
\hline A0 & $132 \mathrm{kV}$ \\
A-high & $50 \mathrm{kV}$ \\
A-low & $50 / 10 \mathrm{kV}$ transformer \\
B-high & $10 \mathrm{kV}$ \\
B-low & $10 / 0.4 \mathrm{kV}$ transformer \\
C & $0.4 \mathrm{kV}$ \\
\hline
\end{tabular}

A new tariff model called "tarifmodel 3.0" that extends the DDT 2.0 model was introduced in 2020 by Dansk Energi [49], and is expected to be in use in 2022. In the Tariff model 3.0, the distribution tariffs are time differentiated, the tariff in each time period equals the flat rate tariff 2021 multiplies the corresponded tariff scaling factor (as shown in Table 12). For instance, the new tariff for $0-6$ am in winter is $3.85 \mathrm{Ore} / \mathrm{kWh}(=11.56 \times 1 / 3)$ which is one-third of the flat rate tariff in 2021.

Table 12. Load periods and Tariff scaling factor in new distribution tariffs for households [49-51].

\begin{tabular}{|c|c|c|c|c|c|}
\hline \multirow[t]{2}{*}{ Hours } & \multicolumn{2}{|c|}{ Winter } & \multicolumn{2}{|c|}{ Summer } & \multirow[t]{2}{*}{$\begin{array}{l}\text { Flat rate Distribution Tariff } * * * * \text { in } \\
2021(\text { Ore } * * / k W h)\end{array}$} \\
\hline & $\begin{array}{l}\text { New Tariff * } \\
\left(\text { Ore }^{* *} / \mathrm{kWh}\right)\end{array}$ & $\begin{array}{c}\text { Tariff Scaling } \\
\text { Factor } * * *\end{array}$ & $\begin{array}{c}\text { New Tariff } \\
(\text { Ore } * * / k W h)\end{array}$ & $\begin{array}{c}\text { Tariff Scaling } \\
\text { Factor }\end{array}$ & \\
\hline $0-6$ & 3.85 & $1 / 3$ & 3.85 & $1 / 3$ & \multirow{4}{*}{11.56} \\
\hline $6-17$ & 11.56 & 1 & 5.78 & $1 / 2$ & \\
\hline $17-21$ & 34.68 & 3 & 15.03 & 1.3 & \\
\hline $21-24$ & 11.56 & 1 & 5.78 & $1 / 2$ & \\
\hline
\end{tabular}

${ }^{*}$ New tariff $=$ Flat rate distribution tariff in 2021 multiplied by the Tariff scaling factor. ${ }^{* *} 100$ Ore $=1$ Danish kroner $\approx 0.13$ euro. ${ }^{* * *}$ Called "tarifskaleringsfaktor" in Danish. ${ }^{* * * *}$ Each DSO in Denmark can decide their DSO tariff. The DSO tariff in this table is provided by a Danish DSO who is responsible for the distribution grid of the selected area.

Table 12 shows that this Tariff model 3.0 (DDT 3.0) uses a ToU pricing structure that has been implemented in many regions. There are three price levels in a day (similar to the DDT number 11 from Table 3) in this tariff model and it does not require electricity consumers to take any extra actions.

Meanwhile, this model is designed following $\$ 73$ in the Danish law of electricity supply [10] and article 18 in the European Union's electricity ordinance [47]. According to Table 12, tariffs for winter and summer are different due to the grid operation cost is higher in winter; there are four time periods with three pricing levels to take flexibility into consideration; this tariff model is applied for all households under the same DSO. Therefore, this Tariff model 3.0 can be defined as: reasonable; non-discriminating; objective; reflecting the true costs; transparent; taking grid security and flexibility into consideration.

According to the evaluation result, this Tariff model 3.0 has the highest levels of technical, economic, social, and regulatory feasibility, and is suitable for implementation in Denmark. Therefore, the developed feasibility evaluation method for DDTs can be proved useful not only for evaluating DDTs in literature but also in DDTs to be in practice.

\section{Conclusions}

This paper introduces a feasibility evaluation method with four dimensions of technical, economic, social, and regulatory. To introduce and demonstrate the developed feasibility evaluation method, a scoping review is conducted and 29 references are selected and further categorized into five attributes of rationale, cost drivers, dynamics, events, and active demand. The dynamic distribution tariffs in literature can be categorized into: Real-Time Pricing, Time-of-Use, Critical Peak Pricing, Consumption-based Time-of-Use, and Consumption-based Real-Time Pricing. 
The dynamic distribution tariffs in literature are evaluated with the developed feasibility evaluation method, and the evaluation results show that the Time-of-Use tariff is the most feasible dynamic distribution tariff, although, Real-Time Pricing is the most popularly discussed in the literature.

To verify the evaluation method, a proposal for the future distribution tariff in Denmark and a Danish DSO are evaluated, and the result proves that the feasibility evaluation method can ensure dynamic distribution tariffs to be feasible and applicable in a region.

\subsection{Contributions}

The developed feasibility evaluation method for dynamic distribution tariffs can fill the research gap of no sufficient method available to review and evaluate dynamic distribution tariffs. This method not only can evaluate dynamic distribution tariffs, but also potentially evaluate any solution (e.g., technology, algorithm, or business model) in an energy ecosystem.

The developed feasibility evaluation method includes four dimensions that represent the technology readiness level, monetary participation cost, user convenience level, and the regulatory readiness level. Meanwhile, each dimension includes several levels and a higher level/scale means higher feasibility a DDT has. A total score that equals the sum of all four dimensions' scores can indicate the overall feasibility of a dynamic distribution tariff. It allows easy identification of the most feasible tariff to implement.

Moreover, except for the regulatory dimension, the other three are consumer-oriented. Fundamentally, the design of dynamic distribution tariffs needs to comply with the regulation. However, the implementation should consider electricity consumers' adoption potentials which the technical, economic, and social feasibility dimensions reflect on.

Although some dynamic distribution tariffs are promising for creating incentives for the consumers to reduce or shift their energy consumption in literature, e.g., Real-Time Pricing, they can not be implemented in practice not only due to the regulation constraints but also the low consumer adoption. Therefore, the developed feasibility evaluation method with four dimensions can ensure a given dynamic distribution tariff to match a targeted regional/national requirement.

\subsection{Limitation and Future Works}

The goal of dynamic distribution tariffs is to create incentives for consumers to reduce or shift their energy consumption and avoid grid congestion. However, the way in which the designed dynamic distribution tariffs will impact electricity consumer behaviors of energy use, especially with distributed energy resources, e.g., electric vehicle charging, is unknown. Meanwhile, whether the combination of dynamic distribution tariffs, hourly electricity pricing, DR programs, and smart algorithms can provide the sustainability and resilience of the distribution grids remains unclear.

Therefore, further works, e.g., simulations with various what-if scenarios and multiobjective optimization are recommended. Especially, agent-based simulations with the consideration from different stakeholders' perspectives are needed [52]. Meanwhile, besides Time-of-Use tariff, other types of dynamic distribution tariffs in the literature are recommended to be further investigated for understanding their impacts on the energy ecosystem [53]. The result can contribute to design the most suitable tariffs and justify regulations to support the sustainability and resilience of the whole energy ecosystem.

Author Contributions: Conceptualization, K.C. and Z.M.; Methodology, K.C. and Z.M.; WritingZ.M. and K.C.; Review and Editing, B.N.J.; Supervision, Z.M. and B.N.J. All authors have read and agreed to the published version of the manuscript.

Funding: This research is part of the national project-Flexible Energy Denmark FED funded by Innovation Fund Denmark.

Institutional Review Board Statement: Not applicable. 
Informed Consent Statement: Not applicable.

Conflicts of Interest: The authors declare no conflict of interest.

$\begin{array}{ll}\text { Abbreviations } \\ \text { Term } & \text { Description } \\ \text { CCP } & \text { Critical Consumption Pricing } \\ \text { CPP } & \text { Critical Peak Pricing } \\ \text { CPR } & \text { Critical Peak Rebate } \\ \text { DDT } & \text { Dynamic Distribution Tariff } \\ \text { DER } & \text { Distributed Energy Resource } \\ \text { DR } & \text { Demand Response } \\ \text { DSO } & \text { Distribution System Operator } \\ \text { EV } & \text { Electric Vehicle } \\ \text { RTP } & \text { Real Time Pricing } \\ \text { ToU } & \text { Time-of-Use } \\ \text { TRL } & \text { Technology Readiness Level }\end{array}$

Appendix A

Table A1. Technology Readiness Level scale [43].

\begin{tabular}{|c|c|c|}
\hline TRL Level & Title & Description \\
\hline 1 & $\begin{array}{c}\text { Basic principles } \\
\text { observed }\end{array}$ & $\begin{array}{l}\text { - Identification of the new concept. } \\
\text { - } \quad \text { Identification of the integration of the concept. } \\
\text { - } \quad \text { Identification of expected barriers. } \\
\text { - } \quad \text { Identification of applications. } \\
\text { - } \quad \text { fdentification of materials and technologies based on theoretical } \\
\text { - Preliminary evaluation of potential benefits of the concept over the existing ones. }\end{array}$ \\
\hline 2 & $\begin{array}{c}\text { Technology } \\
\text { concept formulated }\end{array}$ & 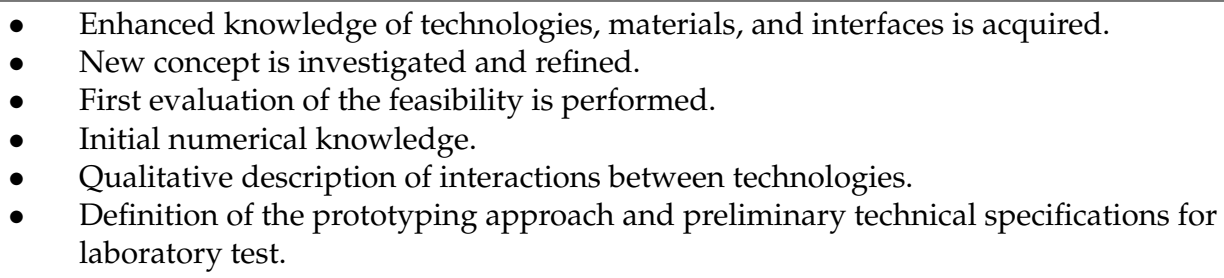 \\
\hline 3 & $\begin{array}{l}\text { Experimental proof } \\
\text { of concept }\end{array}$ & $\begin{array}{l}\text { - First laboratory scale prototype (proof-of-concept) or numerical model realized. } \\
\text { - Testing at laboratory level of the innovative technological element (being material, } \\
\text { sub-component, software tool, ... ), but not the whole integrated system. } \\
\text { - Key parameters characterizing the technology (or the fuel) are identified. } \\
\text { - Verification of the proof of concept through simulation tools and cross-validation } \\
\text { with literature data (if applicable). }\end{array}$ \\
\hline 4 & $\begin{array}{c}\text { Technology } \\
\text { validated in lab }\end{array}$ & $\begin{array}{l}\text { - (Reduced scale) prototype developed and integrated with complementing } \\
\text { subsystems at laboratory level. } \\
\text { Validation of the new technology through enhanced numerical analysis (if } \\
\text { applicable). } \\
\text { - Key Performance Indicators are measurable. } \\
\text { - The prototype shows repeatable/stable performance (either TRL4 or TRL5, } \\
\text { depending on the technology) }\end{array}$ \\
\hline
\end{tabular}


Table A1. Cont.

\begin{tabular}{|c|c|c|}
\hline TRL Level & Title & Description \\
\hline 5 & $\begin{array}{l}\text { Technology } \\
\text { validated in } \\
\text { relevant } \\
\text { environment }\end{array}$ & $\begin{array}{l}\text { - Integration of components with supporting elements and auxiliaries in the (large } \\
\text { scale) prototype. } \\
\text { - } \quad \text { Robustness is proven in the (simulated) relevant working environment. } \\
\text { The prototype shows repeatable/stable performance (either TRL4 or TRL5, } \\
\text { depending on the technology). } \\
\text { The process is reliable and the performances match the expectations (either TRL5 or } \\
\text { TRL6, depending on the technology). } \\
\text { Other relevant parameters concerning scale-up, environmental, regulatory and } \\
\text { socio-economic issues are defined and qualitatively assessed. }\end{array}$ \\
\hline 6 & $\begin{array}{l}\text { Technology pilot } \\
\text { demonstrated in } \\
\text { relevant } \\
\text { environment }\end{array}$ & $\begin{array}{l}\text { - Demonstration in relevant environment of the technology fine-tuned to a variety of } \\
\text { operating conditions. } \\
\text { The process is reliable and the performances match the expectations (either TRL5 or } \\
\text { TRL6, depending on the technology). } \\
\text { - Interoperability with other connected technologies is demonstrated. } \\
\text { - } \quad \text { Manufacturing approach is defined (either TRL6 or TRL7, depending on the } \\
\text { technology). } \\
\text { Environmental, regulatory and socio-economic issues are addressed. }\end{array}$ \\
\hline 7 & $\begin{array}{l}\text { System prototype } \\
\text { demonstration in } \\
\text { operational } \\
\text { environment }\end{array}$ & 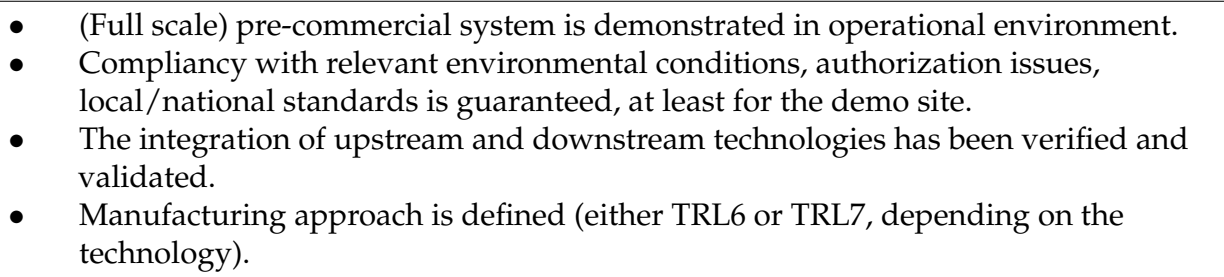 \\
\hline 8 & $\begin{array}{l}\text { System complete } \\
\text { and qualified }\end{array}$ & $\begin{array}{l}\text { - Technology experimented in deployment conditions (i.e., real world) and has proven } \\
\text { its functioning in its final form. } \\
\text { - } \quad \text { Manufacturing process is stable enough for entering a low-rate production. } \\
\text { - } \quad \text { Training and maintenance documentation is completed. } \\
\text { - } \quad \text { Fullegration at system level is completed and mature. } \\
\text { markets. }\end{array}$ \\
\hline 9 & $\begin{array}{l}\text { Actual system } \\
\text { proven in } \\
\text { operational } \\
\text { environment }\end{array}$ & $\begin{array}{l}\text { - Technology proven fully operational and ready for commercialization } \\
\text { - } \quad \text { Full production chain is in place and all materials are available } \\
\text { - } \quad \text { System optimized for full rate production }\end{array}$ \\
\hline
\end{tabular}

\section{References}

1. Mlecnik, E.; Parker, J.; Ma, Z.; Corchero, C.; Knotzer, A.; Pernetti, R. Policy challenges for the development of energy flexibility services. Energy Policy 2020, 137, 111147. [CrossRef]

2. Ma, Z.; Billanes, J.D.; Kjargaard, M.B.; Jorgensen, B.N. Energy flexibility in retail buildings: From a business ecosystem perspective. In Proceedings of the 2017 4th International Conference on the European Energy Market (EEM), Dresden, Germany, 6-9 June 2017; IEEE: Piscataway, NJ, USA, 2017; pp. 1-6. [CrossRef]

3. Ma, Z.; Sommer, S.; Jorgensen, B.N. The smart grid impact on the Danish DSOs' business model. In Proceedings of the 2016 IEEE Electrical Power and Energy Conference (EPEC), Ottawa, ON, Canada, 12-14 October 2016; pp. 1-5. [CrossRef]

4. Smart Consumer-Smart Customer-Smart Citizen (S3C). Guideline: Designing a Dynamic Tariff. Available online: https://www.smartgrid-engagement-toolkit.eu/fileadmin/s3ctoolkit/user/guidelines/GUIDELINE_DESIGNING_A_ DYNAMIC_TARIFF.pdf (accessed on 2 March 2021).

5. Howard, D.A.; Ma, Z.; Engvang, J.A.; Hagenau, M.; Jørgensen, K.L.; Olesen, J.F.; Jørgensen, B.N. Optimization of Energy Flexibility in Cooling Process for Brewery Fermentation with Multi-Agent Simulation. In Proceedings of the 6th IEEJ International Workshop on Sensing, Actuation, Motion Control, and Optimization, Shibaura Institute of Technology, Tokyo, Japan, 16 March 2020; p. TT-16. Available online: http://id.nii.ac.jp/1031/00127065/ (accessed on 13 October 2020).

6. Christensen, K.; Ma, Z.; Demazeau, Y.; Jørgensen, B.N. Agent-based Modeling for Optimizing $\mathrm{CO}_{2}$ Reduction in Commercial Greenhouse Production with the Implicit Demand Response. In Proceedings of the 6th IEEJ International Workshop on Sensing, Actuation, Motion Control, and Optimization (SAMCON2020), Tokyo, Japan, 14-16 March 2020; Available online: http:/ /id.nii.ac.jp/1031/00127067/ (accessed on 13 October 2020). 
7. Eurpoean Commission. Demand Response-Empowering the European Consumer. Available online: https://setis.ec.europa.eu/ publications/setis-magazine/smart-grids/demand-response-empowering-european-consumer (accessed on 16 March 2021).

8. Ma, Z.; Prljaca, Z.; Jørgensen, B.N. The international electricity market infrastructure-insight from the nordic electricity market. In Proceedings of the 2016 13th International Conference on the European Energy Market (EEM), Porto, Portugal, 6-9 June 2016; pp. $1-5$.

9. Christensen, K.; Ma, Z.; Verbak, M.; Demazeau, Y.; Jorgensen, B.N. Agent-based Decision Making for Adoption of Smart Energy Solutions. In Proceedings of the 2019 IEEE Sciences and Humanities International Research Conference (SHIRCON), Lima, Peru, 12-15 November 2019; pp. 1-4. [CrossRef]

10. Danske Love. Elforsyningsloven. Available online: https://danskelove.dk/elforsyningsloven (accessed on 26 February 2021).

11. Ma, Z.; Broe, M.; Fischer, A.; Sorensen, T.B.; Frederiksen, M.V.; Joergensen, B.N. Ecosystem Thinking: Creating Microgrid Solutions for Reliable Power Supply in India's Power System. In Proceedings of the 2019 1st Global Power, Energy and Communication Conference (GPECOM), Nevsehir, Turkey, 12-15 June 2019; pp. 392-397.

12. Ma, Z.; Santos, A.Q.; Gamborg, F.; Nielsen, J.F.; Johannesen, J.M.; Dahl, M.; Jensen, H.; Pedersen, M.R.; Jorgensen, B.N. Solutions for Remote Island Microgrids: Discussion and analysis of Indonesia's remote island energy system. In Proceedings of the International Conference on Innovative Smart Grid Technologies (IEEE PES ISGT Asia 2018), Singapore, 22-25 May 2018; IEEE: Piscataway, NJ, USA, 2018.

13. Ma, Z.; Bloch-Hansen, K.; Buck, J.W.; Hansen, A.K.; Henriksen, L.J.; Thielsen, C.F.; Santos, A.Q.; Jorgensen, B.N. Peer-to-Peer Trading Solution for Microgrids in Kenya. In Proceedings of the 2018 IEEE PES/IAS PowerAfrica Conference-River Club, Cape Town, South Africa, 25-29 June 2018; IEEE: Piscataway, NJ, USA, 2018.

14. O'Connell, N.; Wu, Q.; Ostergaard, J.; Nielsen, A.H.; Cha, S.T.; Ding, Y. Electric Vehicle (EV) charging management with dynamic distribution system tariff. In Proceedings of the 2011 2nd IEEE PES International Conference and Exhibition on Innovative Smart Grid Technologies, Manchester, UK, 5-7 December; pp. 1-7. [CrossRef]

15. Ding, Y.; Li, Y.; Pineda, S.; Østergaard, J.; Jin, T. The impact of dynamic electricity tariff on long-run incremental cost. In Proceedings of the 2012 IEEE Power and Energy Society General Meeting, San Diego, CA, USA, 22-26 July 2012 ; pp. 1-5. [CrossRef]

16. Gu, Y.; Xie, J.; Chen, X.; Yu, K.; Chen, Z.; Li, Z. Dynamic tariff method for congestion management in distribution networks. In Proceedings of the 2017 IEEE Conference on Energy Internet and Energy System Integration (EI2), Beijing, China, 26-28 November 2017; pp. 1-6. [CrossRef]

17. Haendel, M.; Stute, J. Grid Expansion Costs Considering Different Price Control Strategies of Power-to-X Options Based on Dynamic Tariffs at the Low-Voltage Level. In Proceedings of the 2019 16th International Conference on the European Energy Market (EEM), Ljubljana, Slovenia, 18-20 September 2019; pp. 1-6. [CrossRef]

18. Huang, S.; Wu, Q. Dynamic Tariff-Subsidy Method for PV and V2G Congestion Management in Distribution Networks. IEEE Trans. Smart Grid 2019, 10, 5851-5860. [CrossRef]

19. Huang, S.; Wu, Q.; Cheng, L.; Liu, Z. Optimal Reconfiguration-Based Dynamic Tariff for Congestion Management and Line Loss Reduction in Distribution Networks. IEEE Trans. Smart Grid 2016, 7, 1295-1303. [CrossRef]

20. Huang, S.; Wu, Q.; Cheng, L.; Liu, Z.; Zhao, H. Uncertainty Management of Dynamic Tariff Method for Congestion Management in Distribution Networks. IEEE Trans. Power Syst. 2016, 31, 4340-4347. [CrossRef]

21. Huang, S.; Wu, Q.; Nielsen, A.H.; Zhao, H.; Liu, Z. Long term incentives for residential customers using dynamic tariff. In Proceedings of the 2015 IEEE PES Asia-Pacific Power and Energy Engineering Conference (APPEEC), Brisbane, Australia, 15-18 November 2015; pp. 1-5. [CrossRef]

22. Huang, S.; Wu, Q.; Shahidehpour, M.; Liu, Z. Dynamic Power Tariff for Congestion Management in Distribution Networks. IEEE Trans. Smart Grid 2019, 10, 2148-2157. [CrossRef]

23. Huang, S.; Wu, Q.; Zhao, H.; Li, C. Distributed Optimization-Based Dynamic Tariff for Congestion Management in Distribution Networks. IEEE Trans. Smart Grid 2017, 10, 184-192. [CrossRef]

24. Khan, G.M.; Arshad, R.; Khan, N.M. Efficient Prediction of Dynamic Tariff in Smart Grid Using CGP Evolved Artificial Neural Networks. In Proceedings of the 2017 16th IEEE International Conference on Machine Learning and Applications (ICMLA), Cancun, Mexico, 18-21 December 2017; pp. 493-498. [CrossRef]

25. Kumar, M.S.; Srinivasan, S.; Subathra, B. Demand Response Program for Shiftable Modes in Variable Tariff Zones of an Utility. In Proceedings of the 2020 th International Conference on Intelligent Computing and Control Systems (ICICCS), Madurai, India, 13-15 May 2020; pp. 1044-1049. [CrossRef]

26. Oldewurtel, F.; Ulbig, A.; Morari, M.; Andersson, G. Building control and storage management with dynamic tariffs for shaping demand response. In Proceedings of the 2011 2nd IEEE PES International Conference and Exhibition on Innovative Smart Grid Technologies, Manchester, UK, 5-7 December 2011; pp. 1-8. [CrossRef]

27. Pereyra-Zamora, F.H.; Tahan, C.M.V.; Kagan, N.; Moreira, H.L. An Infrastructure of Dynamic Tariff Management and Demand Response applied to Smart Grids using Renewable Energy Resources and Energy Storage Systems. In Proceedings of the 2019 IEEE PES Innovative Smart Grid Technologies Conference-Latin America (ISGT Latin America), Gramado City, Brazil, 15-18 September 2019; pp. 1-6. [CrossRef] 
28. Rasmussen, T.B.; Wu, Q.; Huang, S. Real time emulation of dynamic tariff for congestion management in distribution networks. In Proceedings of the 2016 Asian Conference on Energy, Power and Transportation Electrification (ACEPT), Singapore, 25-27 October 2016; pp. 1-6. [CrossRef]

29. Ribeiro, C.; Pinto, T.; Faria, P.; Ramos, S.; Vale, Z.; Baptista, J.; Soares, J.; Navarro-Caceres, M.; Corchado, J.M. Dynamic electricity tariff definition based on market price, consumption and renewable generation patterns. In Proceedings of the $2018 \mathrm{Clemson}$ University Power Systems Conference (PSC), Charleston, SC, USA, 4-7 September 2018; Institute of Electrical and Electronics Engineers (IEEE): Piscataway, NJ, USA, 2018; pp. 1-5.

30. Huang, S.; Wu, Q.; Liu, Z.; Zhao, H. Sensitivity analysis of dynamic tariff method for congestion management in distribution networks. In Proceedings of the 2015 IEEE Power \& Energy Society General Meeting, Denver, CO, USA, 26-30 July 2015; pp. 1-6. [CrossRef]

31. Shen, F.; Huang, S.; Wu, Q.; Repo, S.; Xu, Y.; Ostergaard, J. Comprehensive Congestion Management for Distribution Networks Based on Dynamic Tariff, Reconfiguration, and Re-Profiling Product. IEEE Trans. Smart Grid 2018, 10, 4795-4805. [CrossRef]

32. Ulbig, A.; Andersson, G. Towards variable end-consumer electricity tariffs reflecting marginal costs: A benchmark tariff. In Proceedings of the 2010 7th International Conference on the European Energy Market, Madrid, Spain, 23-25 June 2010; pp. 1-6. [CrossRef]

33. Lutz, O.; Hollinger, R.; Olavarria, V.; Wittwer, C. Time-optimized dynamic two-step tariffs for CHP operation. In Proceedings of the International ETG Congress 2017, Bonn, Germany, 28-29 November 2017; pp. 1-6.

34. Lutz, O.; Olavarria, V.; Hollinger, R.; Wittwer, C.; Koch, B. Dynamic tariff design for a robust smart grid concept: An analysis of global vs. local incentives. In Proceedings of the 2017 IEEE PES Innovative Smart Grid Technologies Conference Europe (ISGT-Europe), Turin, Italy, 26-29 September 2017; pp. 1-6. [CrossRef]

35. Malatji, E.M. The use of Dynamic Tariff by The Utilities to Counter act The Influence of Renewable Energy Sources. In Proceedings of the 2019 7th International Conference on Smart Grid (icSmartGrid), Newcastle, Australia, 9-11 December 2019; pp. 103-107. [CrossRef]

36. Fischer, D.; Stephen, B.; Flunk, A.; Kreifels, N.; Lindberg, K.B.; Wille-Haussmann, B.; Owens, E.H. Modeling the Effects of Variable Tariffs on Domestic Electric Load Profiles by Use of Occupant Behavior Submodels. IEEE Trans. Smart Grid 2016, 8, 2685-2693. [CrossRef]

37. Philippou, N.; Hadjipanayi, M.; Makrides, G.; Efthymiou, V.; Georghiou, G.E.; Nikolas, P. Effective dynamic tariffs for price-based Demand Side Management with grid-connected PV systems. In Proceedings of the 2015 IEEE Eindhoven PowerTech, Eindhoven, The Netherlands, 29 June-2 July 2015; pp. 1-5. [CrossRef]

38. Pires, G.; Saraiva, J.; Nunes, J.; Pinto, R.B.; Fidalgo, J. Dynamic Network Tariffs: Are they the Most Efficient Way to Match Peak Consumption and Network Incremental Costs? In Proceedings of the CIRED Workshop, Helsinki, Finland, 14-15 June 2016; pp. 1-4. [CrossRef]

39. Skytte, K.; Bergaentzle, C.; Soysal, E.R.; Olsen, O.J. Design of grid tariffs in electricity systems with variable renewable energy and power to heat. In Proceedings of the 2017 14th International Conference on the European Energy Market (EEM), Dresden, Germany, 6-9 June 2017; pp. 1-7. [CrossRef]

40. Saraiva, J.T.; Fidalgo, J.N.; Pinto, R.B.; Soares, R.; Afonso, J.S.; Pires, G. Implementation of dynamic tariffs in the Portuguese electricity system-Preliminary results of a Cost-Benefit Analysis. In Proceedings of the 2016 13th International Conference on the European Energy Market (EEM), Porto, Portugal, 6-9 June 2016; pp. 1-5. [CrossRef]

41. Tonge, K.; Mane, V.; Burad, S.; Urkunde, V.; Aghav, K. Demand based Variable Electricity Tariff Meter. In Proceedings of the 2020 International Conference on Communication and Signal Processing (ICCSP), Chennai, India, 28-30 July 2020; pp. 1452-1455. [CrossRef]

42. Verma, S.K.; Shandilya, A. Variable tariff energy meter with automatic power flow control. In Proceedings of the 2017 International Conference on Energy, Communication, Data Analytics and Soft Computing (ICECDS), Chennai, India, 1-2 August 2017; pp. 58-61. [CrossRef]

43. Innovationsfonden. TRL-Technology Readiness Level. Available online: https://innovationsfonden.dk/sites/default/files/20 19-03/technology_readiness_levels_-_trl.pdf (accessed on 16 March 2020).

44. TWI. What are Technology Readiness Level (TRL)? Available online: https:/ /www.twi-global.com/technical-knowledge/faqs / technology-readiness-levels (accessed on 5 April 2021).

45. Santos, A.Q.; Ma, Z.; Olsen, C.G.; Jørgensen, B.N. Framework for Microgrid Design Using Social, Economic, and Technical Analysis. Energies 2018, 11, 2832. [CrossRef]

46. Circuit Globe. Electricity Tariffs. Available online: https:/ / circuitglobe.com/electricity-tariffs.html (accessed on 2 March 2021).

47. European Union. Europa-Parlamentets og Rådets Forordning (EU) 2019/943 af 5. Juni 2019 om det Indre Marked for Elektricitet. Available online: https:/ / eur-lex.europa.eu/legal-content/da/TXT/?uri=CELEX\%3A32019R0943 (accessed on 2 March 2021).

48. Dansk Energi, Principnotat tarifmodel 2.0. 2015. Available online: https://www.danskenergi.dk/sites/danskenergi.dk/files/ media/dokumenter/2017-10/PrincipnotatTarifmodel20.pdf (accessed on 12 May 2021).

49. Dansk Energi. Principnotat Tarifmodel 3.0; Internal Report; Dansk Energi: Frederiksberg, Denmark, 2020.

50. Dansk Energi. Bilag 1-Omkostningskategorier og priselementer i Tarifmodel 3.0; Internal Report; Dansk Energi: Frederiksberg, Denmark, 2020. 
51. Deshpande, A.; Guestrin, C.; Madden, S.R.; Hellerstein, J.M.; Hong, W. Model-driven data acquisition in sensor networks. In Proceedings of the Thirtieth International Conference on Very Large Data Bases-Volume 30, Toronto, ON, Canada, 31 August-3 September 2004.

52. Ma, Z.; Schultz, M.J.; Christensen, K.; Værbak, M.; Demazeau, Y.; Jørgensen, B.N. The Application of Ontologies in Multi-Agent Systems in the Energy Sector: A Scoping Review. Energies 2019, 12, 3200. [CrossRef]

53. Ma, Z. Business ecosystem modeling- the hybrid of system modeling and ecological modeling: An application of the smart grid. Energy Inform. 2019, 2, 1-24. [CrossRef] 